\title{
KESANTUNAN BERBAHASA DALAM PROSES PEMBELAJARAN DI SEKOLAH DASAR
}

\author{
Diani Febriasari ${ }^{1}$, Wenny Wijayanti ${ }^{2}$ \\ Email: diani_febriasari@yahoo.com
}

Universitas Katolik Widya Mandala Madiun

\begin{abstract}
Abstrak
Di dalam lingkungan sekolah, siswa harusnya lebih bisa mengendalikan tuturan mereka.Hal ini terjadi karena di lingkungan sekolah adalah tempat mereka menuntut ilmu dan membentuk karakter. Akan tetapi pada kenyataannya dalam proses pengajaran masih ditemukan beberapa siswa yang menggunakan bahasa tidak santun kepada teman bahkan kepada guru. Penelitian ini bertujuan mendeskripsikan bentuk pematuhan dan pelanggaran prinsip kesantunan berbahasa pada siswa kelas V Sekolah Dasar.Penelitian ini menggunakan pendekatan deskriptif kualitatif. Data penelitian berupa dialog maupun konversasi siswa dengan temannya dan siswa dengan guru. Pengumpulan data dalam penelitian ini menggunakan metode observasi, teknik rekam, dan wawancara. Dari hasil penelitian ditemukan adanya tuturan siswa yang mematuhi maksim kebijaksanaan, maksim kedermawanan, maksim penghargaan, maksim kesederhanaan, maksim permufakatan, dan maksim kesimpatisan. Akan tetapi adapula tuturan siswa yang melanggar maksim kebijaksanaan, maksim kedermawanan, maksim penghargaan, maksim kesederhanaan, maksim permufakatan, dan maksim kesimpatisan.
\end{abstract}

kata kunci: kesantunan berbahasa, pembelajaran

\begin{abstract}
In the school environment, students should be able to have better control of their speech. This happens because school environment is the place where they study and form the characters. However, the reality in teaching process, there are still some students who use impolite language to friends even to the teachers. The research aims to describe the forms of compliance and violation politenessprinciples at fifth grade students of Elementary School.This study employs descriptive qualitative approach. The data of the research are dialogues and conversations among the students and students with teachers. The data collecting technique of this research are observation, recording and interview. The findings of this study showed that there were students' utterances that complytact maxim, generosity maxim, approbation maxim, modesty maxim, and sympathymaxim. However, there were also students' utterances that violates tact maxim,generosity maxim, approbation maxim, modesty maxim, and sympathymaxim.
\end{abstract}

keywords: language politeness, learning

\section{PENDAHULUAN}

Manusia
bahasa untuk berinteraksi dan bersosialisasi denganharapan terjadi keharmonisan dalam masyarakat. Akan tetapi penggunaan bahasa ini tidak semudah yang dibayangkan. Hal ini terjadi karena dalam berkomunikasi harus memperhatikan mitra tutur dan situasi tuturan agar tujuan dari komunikasi dapat tersampaikan dengan baik. Masyarakat harus memperhatikan sopan santun dalam berbicara jangan sampai mengeluarkan kata-kata yang menyinggung perasaan atau kehormatan orang lain (Dwijawijaya, 1974: 80).
Semakin berkembangnya budaya, semakin banyak anak-anak yang kurang santun dalam bertutur sehingga dapat menyinggung perasaan mitra tutur.Anak yang kurang mendapat perhatian dalam bertutur dari orang tua dan guru akan menjadi momok dalam lingkungan masyarakat. Hal ini terjadi karena apabila orang tua memberikan contoh yang kurang baik dalam bertutur, anak pun akan menirukannya (Kusno, 2014: 13).Dalam permasalahan ini orang tua dan guru merupakan faktor utama dalam pembentukan kesopanan berbahasa pada anak.Maka dari itu, orang tua dan guru diharapkan bisa menjadi pembimbing dan panutan

140 | Jurnal Kredo 
anak untuk belajar bahasa dengan baik.

Dengan maraknya bahasa gaul di masyarakat, anak mempunyai penilaian bahwa dengan menggunakan bahasa tersebut ia dapat diterima oleh teman-temannya dan telah mengikuti trend di lingkungannya. Hal ini mengakibatkan lunturnya penggunaan bahasa Indonesia dengan baik dan benar oleh anak terutama saat berkomunikasi secara formal seperti di dalam kelas.Di dalam lingkungan sekolah, siswa harusnya lebih bisa mengendalikan tuturan mereka. Hal ini terjadi karena di lingkungan sekolah adalah tempat mereka menuntut ilmu dan membentuk karakter. Akan tetapi pada kenyataannya dalam proses pengajaran masih ditemukan beberapa siswa yang menggunakan bahasa tidak santun kepada teman bahkan kepada guru. Penggunaan bahasa tidak santun pada siswa terlihat dari tuturan, seperti $d u d u l$ (bodoh), lambreta (lambat), lola (mikir lama), serta mengucapkan berbagai jenis nama binatang dengan nada tinggi dan tidak sesuai dengan konteks seperti "jangkrik, pitik, asu, dan sebagainya.

Dalam penelitiannya, Nuryani menerangkan adanya pelanggaran kesantunan berbahasa dalam proses belajar mengajar seperti contoh tuturan berikut.

$$
\begin{aligned}
& \text { Siswa : "Belum paham } \\
& \text { semuanya bu" } \\
& \quad \text { (salah seorang siswa } \\
& \text { kemudian melanjutkan) } \\
& \begin{array}{l}
\text { Siswa : "Ibu jelasin lagi } \\
\text { dong!" }
\end{array}
\end{aligned}
$$

(kemudian disusul dengan beberapa siswa lain yang ikut

Memberikan

dukungan)

Siswa : "iya bu, Ibu harus jelasin lagi, kami kan gak paham"

Dari data yang dipaparkan dalam tuturan tersebut terlihat ada prinsip kesopanan yang dilanggar. Selain itu, terdapat juga ketidaksantunan yang diperlihatkan siswa melalui penggunaan tuturan langsung yang berupa penolakan. Seperti terlihat pada tuturan tersebut yang konteksnya adalah guru baru selesai memaparkan materi pelajaran, lalu guru menanyakan mengenai pemahaman siswa terkait materi yang baru saja dipaparkannya. Dalam bahasa Indonesia ucapan tidak santun terlihat dari pemakaian kaidah bahasa yang tidak tepat, yaitu ucapan tidak baku dalam bahasa Indonesia. Contoh pemakaian bahasa Indonesia yang tidak baku, yaitu kata "ngumpetin" seharusnya "menyembunyikan", "biarin" seharusnya "biarkan", "makasih" seharusnya "terima kasih", "gak" seharusnya "tidak" , "maap" seharusnya "maaf", "udah" seharusnya "sudah" dan lain-lain.

Dari latar belakang tersebut, peneliti tertarik untuk melakukan penelitian tentang Kesantunan Berbahasa dalam Proses Pembelajaran di Sekolah Dasaryang bertujuan untukmengetahui bentuk pematuhan dan pelanggaran terhadap prinsip-prinsip kesantunan berbahasa pada siswa kelas V Sekolah Dasar. 


\section{KAJIAN TEORI}

\section{Hakikat Tindak Tutur}

Tindak tutur atau dalam istilah Inggris speech act merupakan aktivitas mengujarkan atau menuturkan tuturan dengan maksud tertentu (Rustono, 1999:33). Menurutnya tindak tutur merupakan entitas yang bersifat sentral dalam pragmatik.Maka dari itu, tindak tutur menjadi hal yang penting dan berperan dalam analisis topik pragmatik seperti perikutan,implikatur percakapan, praanggapan, prinsip kerja sama, dan prinsip kesantunan. Menurutnya rasionalitas munculnya istilah tindak tutur yang didasarkan pendapat Purwo (1990) adalah di dalam mengucapkan ekspresi, pembicara tidak semata-mata mengatakan sesuatu dengan mengucapkan ekspresi itu. Dalam pengucapan ekspresi itu ia juga menindakkan sesuatu.Hal penting yang perlu disebutkan sehubungan dengan pengertian tindak tutur itu adalah ujaran (berapapunjumlahnya) bisadikelompokkan dalam lima kategori, yakni representative, direktif, ekspresif, komisif, dan deklaratif (Searle, 1975).

\section{Kesantunan Berbahasa}

Kesantunan berbahasa dalam tuturan pada hakikatnya tergantung pada tiga kaidah yang seharusnya ditaati.Menurut Chaer (2010: 10) kaidah tersebut terdiri dari formalitas, ketidaktegasan, dan kesekawanan atau kesamaan.

Kesantunan berbahasa pada tuturan juga dipengaruhi bidalbidal.Menurut Leech (dalam Rustono, 1999:70-77) prinsip kesantunan didasarkan pada kaidahkaidah.Kaidah tersebut adalah bidal atau pepatah yang memiliki nasihat yang harus ditaati agar penutur dalam bertutur memenuhi prinsipprinsip kesantunan.Prinsip-prinsip kesantunan beserta maksimnya diuraikan sebagai berikut.

\section{Maksim Kebijaksanaan (Tact Maxim)}

Pemikiran utama maksim kebijaksanaan/tact maximdalam prinsipkesantunan yaitu peserta petuturan sebaiknya berpegang terhadap prinsip agar meminimalkan keuntungan bagi diri sendiri sertamemperbanyak keuntungan pihak lain saat berkomunikasi. Apabila dalam bertutur orang berpegang teguh pada maksim kebijaksanaan, ia akan dapat menghindarkan sikap dengki, iri hati, dan sikap-sikap lain yang kurang santun terhadap mitra tutur (Rahardi, 2005: 60).

\section{Maksim Kedermawanan (Generosity Maxim) \\ Dengan}

maksim

kedermawaanatau kemurahan hati, peserta pertuturan dihimbauuntuk menghormati sesama. Penghormatan terhadap orang lain akan terjadi apabila orang dapat mengurangi keuntungan bagi dirinya sendiri dan memaksimalkan keuntungan bagi pihak lain (Rahardi, 2005: 61).

\section{Maksim (Approbation Maxim)}

Di dalam maksim penghargaan/approbation maxim dipaparkan jika seseorang dikatakan santun bila saat berbicara berusaha untuk memberi penghargaan kepada rekan bicara. Penutur dan mitra tutur yang saling mencaci pada saat berkomunikasi dapat digolongkan sebagai manusia yang tidak baik 
maka perbuatan itu harus dihindari dalam pergaulan sesungguhnya (Rahardi, 2005: 62-63).

\section{Maksim Kesederhanaan (Modesty Maxim)}

Di dalam maksim

kesederhanaan/modesty maxim, peserta tutur dihimbau untuk memiliki sikap rendah hati. Kerendahhatian ini dilakukan dengan mengurangi pujian kepada diri sendiri. Orang dikategorikan congkak hati atau sombong bila dalam berbicara sering memuji diri sendiri. Dalam masyarakat bahasa dan budaya Indonesia, kesederhanaan dan kerendahan hati banyak digunakan sebagai parameter penilaian kesantunan seseorang. (Rahardi, 2005: 64).

\section{Maksim Permufakatan (Agreement Maxim)}

Dalam maksim permufakatan/agreement maxim ini diharapkan supaya peserta tutur bisa membina kemufakatan saat berbicara. Di dalam masyarakat tutur Jawa, orang tidak diperbolehkan memenggal atau bahkan membantah secara langsung apa yang dituturkan oleh pihak lain (Rahardi, 2005: 64).

\section{Maksim Kesimpatisan (Sympath Maxim)}

\section{Pada}

maksim

kesimpatisan/sympath maxim, menghimbau kepada peserta tutur agar memaksimalkan sikap simpati antar manusia dalam berbicara. Orang yang bersikap sinis terhadap pihak lain, akan dianggap sebagai orang yang tidak tahu sopan santun di dalam masyarakat (Rahardi, 2005: 65).

\section{Indikator Kesantunan dalam} Topik Pertemuan Resmi Proses Belajar Mengajar

Indikator kesantunan dalam proses belajar mengajar digolongkan menjadi empat katagori, yaitu sangat santun, santun, tidak santun, dan sangat tidak santun. Dalam kegiatan bertanya atau konfirmasi tentang sesuatu penutur dikategorikan santun apabila memakai kata "mohon maaf" dan tidak berprasangka buruk kepada lawan tutur. Dikatakan tidak santun apabila penutur dalam bertutur menuduh apalagi melakukan fitnah kepada lawan tutur.

Ketika seseorang menolak terhadap sesuatu sebaiknya tuturan disampaikan dengan tulus dan jujur sehingga tuturan penutur dapat dikategorikan sebagai tuturan yang sangat santun. Sedangkan apabila penutur menolak dengan kebohongan dan nada kasar maka tuturan tersebut dikatakan sangat tidak santun.

Dalam mengomentari pendapat atau mengkritik karya pihak lain sebaiknya dilakukan dengan sangat santun dengan menggunakan kata "maaf", tidak berpikir buruk dan menyinggung hati pihak lain, serta memberi masukkan dengan pilihan kata yang baik. Jika penutur memberikan saran dengan langsung menggunakan bahasa kasar dan menjelekkan pihak lain di depan umum maka penutur dianggap sangat tidak santun.

Penutur dikatakan sangat santun dalam mengajukan pendapat bila memakai kata "terima kasih", menghormati orang lain, tidak congkak, dan tidak merendahkan argumen pihak lain. Bila dalam berpendapat penutur terlihat arogan, congkak, dan superior maka ia akan terlihat sangat tidak santun. 
Jika menegur peserta didik, penutur yang sangat santun akan mengatakan "maaf", memilih kata yang sesuai, dan tahu tentang nasihat yang mendidik. Berbeda dengan penutur yang sangat tidak santun, ia akan menasihati menggunakan suara keras, memilih kata kasar, serta menjelekkan pihak lain di depan orang banyak ketika menegur peserta didik. (Diadaptasi dari penelitian Zamzani et al, 2011)

\section{METODE PENELITIAN}

Penelitian ini menggunakan desain penelitian deskriptif kualitatif untuk menemukan pelanggaran prinsip kesantunan berbahasa pada siswa kelas V Sekolah Dasar Negeri di Kota Madiun. Data terdiri dari 5 rekaman video pembelajaran di kelas.Pengumpulan data dilaksanakan dengan metode observasi, teknikrekam, dan wawancara.

Tahapan yang peneliti lakukan pada teknik ini adalah (1) Pengumpulan data, yaitu mengumpulkan tuturan siswa dengan guru serta tuturan antarsiswa. Data dikumpulkan dengan merekam tuturan-tuturan di dalam kelas dan mencatat sesuatu yang dianggap penting untuk mendukung data; (2) Reduksi data dilakukan dengan cara memilih data penting lalu menyingkirkan yang tidak tidak. Hasil video rekaman tuturan siswa dengan guru serta tuturan antarsiswa tersebut dipilih sesuai dengan fokus penelitian kemudian dihubungkan dengan pendidikan orang tua; (3) Penyajian data, yaitu mengklasifikasikan data sejenis; (4) Penarikan simpulan, yaitu membuat simpulan dari semua data yang sudah didapat pada awal sampai akhir penelitian.

\section{HASIL DAN PEMBAHASAN}

Berdasarkan hasil analisis terhadap tuturan dalam lima rekaman video pembelajaran di kelas terdapat tuturan-tuturan yang mematuhi dan melanggar prinsip kesantunan berbahasa. Pematuhan kesantunan berbahasa dalam proses pembelajaran di Sekolah Dasar meliputi pematuhan maksim kebijaksanaan, maksim kedermawanan, maksim penghargaan, maksim kesederhanaan, maksim permufakatan, dan maksim kesimpatisan. Dalam rekaman video tersebut juga ditemukan tuturan yang melanggar prinsip kesantunan berbahasa. Pelanggaran tersebut terdiri dari pelanggaran maksim kebijaksanaan, maksim kedermawanan, maksim penghargaan, maksim kesederhanaan, maksim permufakatan, dan maksim kesimpatisan. Berikut bentuk pematuhan dan pelanggaran prinsip kesantunan berbahasa dalam proses pembelajaran di Sekolah Dasar.

\section{Pematuhan Kesantunan Berbahasa dalam Proses Pembelajaran di Sekolah Dasar}

\section{a. Pematuhan Maksim}

\section{Kebijaksanaan}

Pematuhan terhadap maksim kebijaksanaan dalam situasi formal sering dijumpai.Hal tersebut dapat dilihat pada kutipan berikut.
1)
Berikutnya yang
Guru : romawi II.
AWA $: 5 \mathrm{Bu}$. 
Konteks: Guru dan siswa sedang membahas soal. AWA meluruskan pernyataan guru yang seharusnya dibahasa setelah nomor empat adalah nomor lima.

2)

Guru

: Nomor 9.

Semua siswa :(Diam)

Guru : Nomor 9

siapa?

DHW

: Nomor 11

$\mathrm{Bu}$.

Konteks: Penutur (Guru) dan semua siswa sedang membahas soal. Guru menyuruh siswa yang bertugas menjawab pertanyaan nomor 9 untuk segera menjawab. Akan tetapi semua siswa diam karena binggung, lalu DHWmeluruskan

pernyataan guru yang seharusnya dibahas adalah nomor 11 agar semua teman-temannya tidak bingung.

3)

Penutur

: Nomor 4.

Semua siswa : (Diam)

AS : Nomor 2

$\mathrm{Bu}$.

Konteks: Guru dan siswa sedang membahas soal. Guru menyuruh siswa yang bertugas menjawab soal nomor 4 untuk segera menjawab. Akan tetapi semua siswa diam karena bingung, lalu ASmeluruskan pernyataan guru yang seharusnya dibahas adalah nomor 2

agar semua temantemannya tidak bingung.

Data tuturan (1), (2), dan (3) mencerminkan kesantunan yang mendasarkan pada maksim kebijaksanaan. Hal ini terjadi karena mitra tutur memaksimalkan keuntungan bagi guru dan siswa yang lain agar tidak salah membahas soal.
4) AV : Sa... Sa... nyileh

$$
\text { stipo } \quad \text { Sa... }
$$

Oleh?

Konteks: Siswa AV hendak meminjam tipe-x ke temannya.

Data tuturan tersebut menunjukkan bahwa AV telah memenuhi kesantunan berbahasa maksim keijaksanaan karena pada tuturan tersebut siswa AV berusaha meminta izin dengan mengucapkan kata “oleh?" yang menunjukkan permintaan persetujuan dari pemilik barang (tipe-x).

5)

: Ini lho

Konteks: memberikan pentunjuk kepada temannya

Tuturan tersebut mematuhi prinsip kesantunan berbahasa maksim kebijaksanaan. Hal tersebut karena pada tuturan tersebut BRN berusaha untuk memberikan keuntungan pada pihak lain dengan memberikan petunjuk akan apa yang dilakukannya.

\section{b. Pematuhan} Permufakatan

Maksim permufakatan juga dipatuhi dalam tuturan berikut. 
6) DAKP : $\begin{array}{r}\text { Jika } \\ \text { bermain }\end{array}$

Bola...agar...

\begin{tabular}{ll}
$\begin{array}{l}\text { Siswa } \\
\text { bermain }\end{array}$ & \multicolumn{2}{c}{ piye yo? } \\
sebaiknya & bola \\
hati. & berhati- \\
$\begin{array}{l}\text { DAKP } \\
\text { lho. }\end{array}$ & : Lha ngono \\
$\begin{array}{l}\text { Konteks: } \\
\text { berdiskusi } \\
\text { tugas. }\end{array}$ & Siswa saling \\
&
\end{tabular}

Tuturan tersebut dipandang sebagai tuturan yang santun karena memenuhi maksim permufakatan.Dalam tuturan tersebut telah mengusahakan kesepakatan antara penutur (DAKP) dan mitra tutur (teman DAKP) yang dapat dilihat dari tuturan "Lha ngono lho."'Tuturan ini merupakan bentuk kesepakatan yang diungkapkan antara penutur dan mitra tutur.

$\begin{array}{ll}\text { 7) } \begin{array}{ll}\text { Guru } \\ \text { temanmu }\end{array} & \text { Kalau } \\ \text { kelebihan, } & \text { memiliki } \\ & \text { kamu juga }\end{array}$

$\begin{array}{ll}\text { memuji. } & \text { menghargai, } \\ \text { RDK } & \text { : Bu... Bu... } \\ & \text { Bu... } \\ & \text { tidak } \\ & \text { mencontoh } \\ & \text { dan } \\ & \text { mencemooh } \\ & \text { kebudayaan } \\ & \text { orang } \\ & \text { lain. }\end{array}$

Konteks: Guru dan siswa membahas dan memberi contoh cara menghargai orang lain.

Data (7) menaati kesantunan berdasarkan pada maksim permufakatan terlihat ketika RDK menguatkan pernyataan guru untuk dapat menghargai orang lain.

8) ALNA : Ini lho udah

Tuturan tersebut merupakan tuturan yang menerapkan maksim permufakatan. Ini terjadi karena pada tuturan (8) siswa ALNA memberikan kesepahamannya bahwa apa yang telah dikerjakan memang telah selesai.

9) CEJ : Selesai... sudah

Pak..Pak!

Konteks: Pada saat guru menanyakan apakah pekerjaan yang dilakukannya telah selesai dilakukan.

Tuturan tersebut merupakan tuturan yang mematuhi maksim permufakatan. Hal tersebut karena pada tuturan itu CEJ ingin menyepakati apa yang dikehendaki oleh guru bahwa tugas yang dikerjakan telah selesai dilakukan.

\section{c. Pematuhan \\ Kesimpatian}

Maksim

Maksim kesimpatian juga terdapat dalam proses pembelajaran. Hal ini terlihat dalam kutipan berikut.

$\begin{array}{cc}\begin{array}{c}\text { 10) Guru } \\ \text { sudah }\end{array} & \text { : Yang kedua } \\ & \text { menemukan? } \\ \text { Hayo } & \text { siapa? } \\ \text { RRC } & : \text { Wulan Bu }\end{array}$


FJ : Wulan $\mathrm{Bu}$

Guru : O... Wulan.

Oiya

Wulan dulu.

Konteks: Guru menyuruh siswa mengerjakan soal di papan tulis. Ketika Wulan sudah di depan, guru tidak melihat dan tetap menawarkan kepada siswa lain untuk maju. Akhirnya RRC dan FJ memberitahu kepada guru kalau sudah ada yang maju mengerjakan soal, yaitu Wulan.

$$
\text { Pada data (10) }
$$

memperlihatkan kesantunan yang mendasarkan pada maksim kesimpatisan karena RRC dan FJ memberikan simpati kepada Wulan yang sedang mengerjakan tugas di depan kelas ketika Guru tidak tau kalau Wulan sudah menyawab pertanyaan di depan.

$\begin{array}{lrr}\text { 11) Guru } & \text { : } & \text { Sudah } \\ \text { selesai? } & & \\ \mathrm{DAKP} & \text { : } & \text { Kurang dua } \\ \mathrm{Bu} ! & & \\ \mathrm{ARP} & \text { : } & \text { Kurang } \\ \mathrm{Bu} ! & & \\ \text { Konteks: } & \text { Guru } \\ \text { menanyakan } & \text { tentang } \\ \text { keselesaian } & \text { tugas } & \text { siswa. }\end{array}$

Tuturan DAKP dan ARP dianggap sebagai tuturan yang santun. Hal ini terjadi karena mereka memperlihatkan kesimpatisannya dalam mengerjakan tugas yang diberikan guru.Kesimpatisan mereka juga terlihat ketika guru menanyakan tentang keselesaian tugas, meskipun mereka belum selesai mengerjakan tugas tetapi mereka tetap bersimpati untuk menjawab pertanyaan guru.
12) DAKP : Dinilaikan

nggak

$\mathrm{Bu}$ ?

Guru : Dinilaikan.

TVAB : Tinggal satu

$\mathrm{Bu}$.

MYFM : Tinggal satu

$\mathrm{Bu}$.

Konteks: Ketika proses mengerjakan tugas.

Data tuturan (12) juga mencerminkan pematuhan maksim kesimpatisan karena DAKP, TVAB, dan MYFM memperlihatkan sikap simpati mereka terhadap tugas yang diberikan guru.

13) $\mathrm{ADS} \quad: \quad \mathrm{Bu}, \quad$ satu nomor satu

Guru $\quad$ : $\begin{aligned} & \text { tanggapan? } \\ & \text { Bagaimana }\end{aligned}$ teman-

teman?

Konteks: Ketika proses mengerjakan tugas.

Tuturan

ADS memperlihatkan kesimpatiannya dalam mengerjakan tugas. Hal ini terlihat ketika ADS bersemangat mengerjakan tugas dan bertanya ketika ia tidak tahu.

\section{d. Pematuhan \\ Kedermawanan}

Maksim

14) AHCB : Buku kuwi lho.

Konteks: Ahnaf menunjukkan sebuah buku kepada temannya.

Tuturan AHCB tersebut dikategorikan santun sebab memenuhi prinsip kesantunan Leech, yakni maksim kedermawanan. Hal ini terjadi karena AHCB memberikan keuntungan dengan 
menunjukkan sebuah buku kepada temannya.

$\begin{array}{lll}\begin{array}{l}\text { 15) } \mathrm{GH} \\ \text { piye? Iki }\end{array} & \text { Nomer } & 7 \mathrm{ki} \\ & \text { aku } & \text { nulis } \\ \text { puisi? } & & \\ \begin{array}{l}\text { Konteks: bertanya } \\ \text { teman yang lainnya }\end{array} & \text { pada }\end{array}$

Tuturan yang dilakukan oleh GH adalah tuturan yang mematuhi maksim kedermawanan. Ini terjadi karena GH berusaha untuk menghormati atau menghargai orang lain (temannya) dengan mengajukan pertanyaan akan apa yang harus dia lakukan. Tentu hal tersebut merupakan bentuk sebuah penghargaan bagi orang lain, sehingga tuturan tersebut merupakan tuturan yang mencerminkan kesantunan berbahasa.

16) ALNA : Ki lho neng kene!

Konteks: Memberikan jawaban atas pertanyaan yang diberikan oleh mitra tutur.

Tuturan yang terjadi di atas adalah tuturan yang mematuhi maksim kedermawanan. Ini terjadi karena ALNA lebih memberikan keuntungan pada pihak lain dengan memberikan informasi yang dibutuhkan oleh orang lain tersebut.

17) YAC : Suwun
Konteks: Mengucapkan
terima kasih karena telah
dipinjami pengahpus oleh
temannya.

Tuturan (17) termasuk tuturan yang mematuhi maksim kedermawanan. Hal tersebut dapat dilihat pada kata "suwun" yang bermakna terima kasih karena telah diberikan pinjaman penghapus. Hal itu tentu merupakan suatu bentuk penghormatan atau penghargaan kepada pihak lain. Maka tuturan (17) merupakan tuturan yang sudah mematuhi prinsip kesantunan berbahasa.

\section{e. Pematuhan Penghargaan}

18) KLF : Amit ya.

Konteks: Keisha melewati beberapa teman yang menggambar di depan.

Tuturan yang disampaikan KLF tersebut mematuhi maksim penghargaan karena ia memberikan penghormatan kepada temannya ketika ia berjalan melewati temannya dengan mengucapkan kata "amit" yang bermakna "permisi".

\section{Pelanggaran Kesantunan Berbahasa dalam Komunikasi Formal Ditinjau dari Pengaruh Pendidikan Orang Tua}

\section{a. Pelanggaran Maksim \\ Kebijaksanaan}

Dalam lingkup formal ternyata peneliti juga menemukan banyak pelanggaran terhadap maksim kebijaksanaan seperti berikut.
19) ALNA : Awakmu sing nulis!
Konteks: Siswa ALNA menyuruh temannya untuk menulis hasil diskusi mereka.

Tuturan ALNA tersebut merupakan tuturan yang melanggar maksim kebijaksanaan.Hal tersebut 
karena pada tuturan tersebut siswa ALNA tidak memberikan keuntungan bagi temannya karena menyuruh temannya untuk menulis hasil diskusi dan beban tersebut tidak diambilnya sendiri yaitu dengan bersedia menulis hasil diskusi kelompok.

\section{0) YDS : Tak jiplak gambare! \\ Konteks: Siswa mendapat tugas menggambar.}

Tuturan YDS tersebut melanggar maksim kebijaksanaan. Hal ini terjadi karena ketika guru memberi tugas menggambar, ia membuat keuntungan sebesar mungkin kepada dirinya. Keuntungan tersebut ia lakukan dengan mempermudah pekerjaannya, yaitu dengan menjiplak gambar.

21) JFH : Tidak tahu! Konteks: Menyela ketika penutur berbicara

Tuturan tersebut telah melanggar kesantunan berbahasa maksim kebijaksanaan. Hal tersebut karena dalam tuturan, JFH menyela pembicaraan orang lain dengan mengatakan "Tidak tahu". Seharusnya dalam tuturan tersebut JFH mendengarkan terlebih dahulu apa yang disampaian penutur tanpa menyela.

22) JFH :

Ani...Ani...Ani.

Konteks: Menertawakan nama "Ani"

JFH terlihat melanggar maksim kebijaksanaan karena ia tidak menghormati/menghargai orang lain dengan menertawakan nama orang lain.

b. Pelanggaran

Maksim Kedermawanan

23) Guru

: Cari sepuluh persoalan

yang ada

di dalam

kelas secara

berkelompok!

Siswa : Ayo cah papat

Siswa : Sing mikir sopo?

Guru : Hayo gak

usah

tapi

ngomong ae

ndang ngarap

tugas!

ARP : Lha aku?

Konteks: guru meminta siswa mengerjakan tugas secara berkelompok. Akan tetapi ARP protes kepada teman dekatnya karena ia tidak mendapat kelompok bersama mereka.

$\begin{array}{rrr}\text { Cara } & \begin{array}{r}\text { bertutur } \\ \text { dengan }\end{array} & \begin{array}{r}\text { ARP } \\ \text { maksim }\end{array}\end{array}$ kedermawanan. Hal tersebut karena ARP menginginkan dirinya untuk mendapatkan kelompok (menguntungkan dirinya) yang seharusnya seharusnya ia bermurah hati untuk pindah ke kelompok lain sehingga ia dapat mengurangi keuntungan bagi dirinya.

24) Siswa : Bolpenku mengko

tambah ilang. ARP : Aku sik Ju.... Aku 
Sumpah!

$$
\text { sik.... }
$$

\section{Konteks: Berebut bolpoin.}

Dari ucapan ARP, terlihat kalau ARP ingin memperbanyak keuntungannya. Hal ini dilakukannya dengan cara berusaha merebut bolpoin untuk mengerjakan tugas. Pada tuturan tersebut telah terjadi pelanggaran kesantunan berbahasa yaitu pelanggaran maksim kedermawanan.

25) JFH $\quad$ : Tidak tahu Konteks: JFH menyela pembicaraan guru

Tuturan tersebut melanggar maksim kedermawanan karena peserta pertuturan (JFH) tidak memberikan pernghormatan kepada orang lain/penutur dengan menyela tuturan penutur.Seharusnya ketika menjadi mitra tutur, JFH harus menghormati penuturnya dengan tidak menyela pembicaraan penutur.

$$
\begin{aligned}
& \text { 26) YAP : Rana go.... } \\
& \text { Aja ning } \\
& \text { Konteks: YAP mengusir } \\
& \text { temannya yang sedang } \\
& \text { duduk mengerjakan tugas } \\
& \text { karena ia mau maju ke } \\
& \text { depan. }
\end{aligned}
$$

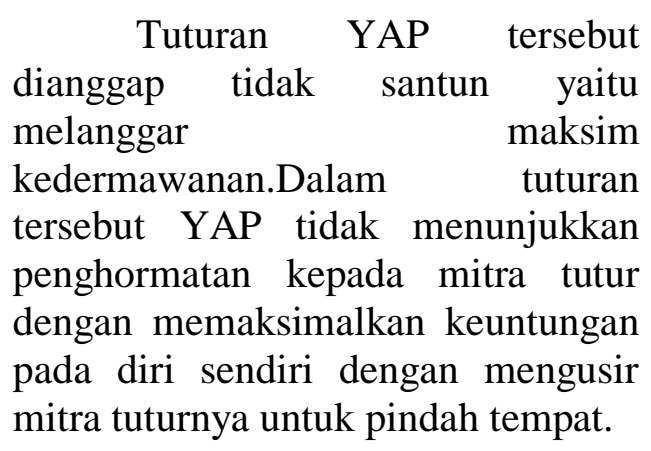

27) MCM : Itu tok? Itu tok?

Konteks: MCM menanyakan secara terus menerus mengenai jawaban yang diberikan oleh temannya.

Tuturan tersebut telah melanggar prinsip kesantunan berbahasa maksim kedermawanan.Hal tersebut karena dalam tuturan tersebut MCM tidak berusaha menghormati penutur dengan menanyakan secara berulang mengenai jawaban yang diberikan.

28) MVA : Uwis?

Konteks: Bertanya pada mitra tutur apakah pekerjaannya telah selesai

Tuturan MVA melanggar maksim kedermawanan. Hal tersebut terlihat pada ucapan MVA yang tidak menghormati mitra tuturnya dengan pilihan kata yang digunakan yaitu dengan bahasa jawa ngoko "uwis".

\section{c. Pelanggaran Maksim Penghargaan \\ 29) MMS : Awas kowe, kowe njupuk engko nek kualat.}

Konteks: MMS menuduh temannya menggambil barangnya.

MMS melanggar maksim Leech dalam menyampaikan tuturannya.Ia melanggar maksim penghargaan karena menuduh temannya mengambil barangnya. Secara tidak langsung ia merendahkan orang lain di depan 
umum sehingga dapat dikatakan kalau Mahen tidak santun.

30) Guru : Mau masuk mas?

\begin{tabular}{lll} 
& \multicolumn{2}{c}{ Kelasnya } \\
mana? & Mau masuk \\
sini? Iya & & \\
sini? & mau masuk
\end{tabular}

AHCB : $\quad$ Masuk

konoooooh!

Konteks: Guru bertanya kepada anak-anak yang ada di luar yang sedang melihat kelas 5. Dengan suara keras dan mengejek, AHCB menyuruh mereka masuk.

Tuturan AHCB tersebut dianggap tidak santun karena melanggar maksim penghargaan.Dia menyela obrolan guru dan anak-anak di luar kelas dengan mengatakan "Masuk konooooh".AHCB seharusnya menghargai keputusan guru, bukannya malah mengejek dan menyuruh anak-anak tersebut masuk ke kelas.

$\begin{array}{cl}\text { 31) Guru } & \begin{array}{c}\text { : Sudah tahu } \\ \text { mengolok- }\end{array} \\ \text { olok itu } & \text { tidak baik, } \\ \text { tetapi } & \begin{array}{l}\text { masih selalu } \\ \text { dilakukan. }\end{array}\end{array}$

Siapa yang sering

melakukan?

$\begin{array}{ll}\text { FINF } & \text { : Deva! } \\ \text { YAP } & \text { : Deva! } \\ \text { RNPA } & \text { : Deva! } \\ \text { DEA } & \text { : Deva! }\end{array}$

Konteks:

Guru

menerangkan tentang cara menghormati orang lain.

Keempat siswa tersebut telah melanggar maksim penghargaan karena dalam tuturan tersebut tampak bahwa mereka mengejek/merendahkan salah satu teman mereka.Tuturan tersebut terlihat merendahkan dan memojokkan temannya sehingga dapat dikatakan sangat tidak santun.
32) Guru : : Hayo siapa yang
selalu
begitu?
BAS : Lha iki malah, Deva.

Konteks:

Guru menerangkan tentang cara menghormati orang lain.

Dalam tuturan tersebut BAS juga melanggar maksim penghargaan karena ikut mengejek dan memojokkan Deva dengan kata-kata yang keras.

33) Guru : Selain yang

kamu

sampaikan

tadi.

Coba cari

persoalan

yang betul-

betul

dalam

terjadi di

kelas. Coba

yang

pertama tadi

apa?

Siswa : Kelas ramai,

main

bola di dalam

kelas, 


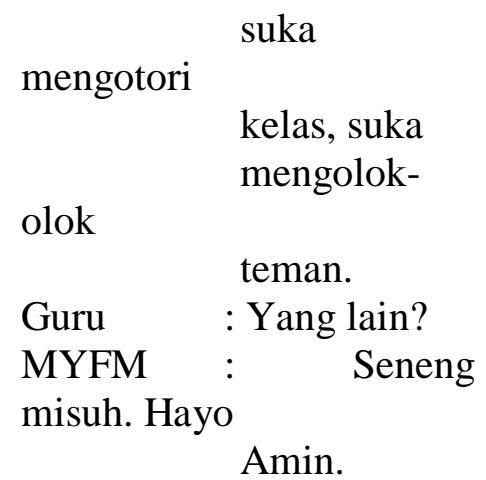

IM : Amin Bu!

Konteks: Guru meminta siswa untuk menemukan tindakan-tindakan yang tidak baik di dalam kelas.

MYFM dan IM melanggar maksim penghargaan dalam menyampaikan tuturannya. Tuturan mereka terlihat memaksimalkan kecaman terhadap temannya dengan mengatakan kekurangan dari Amin yang suka misuh. Dari tuturan MYFM tersebut terlihat kalau mereka menjelekkan dan memojokkan temannya.

$$
\begin{array}{lr}
\text { 34) FINF : Kowe ora } \\
\text { mikir! } \\
\text { Konteks: } \\
\begin{array}{lr}
\text { mengerjakan } & \text { Dalam } \\
\text { kelompok, FINF mengolok } & \text { tugas } \\
\text { teman sekelompoknya. }
\end{array}
\end{array}
$$

FINF telah melanggar maksim penghargaan dalam penyampaian tuturannya. Seharusnya ia meminimalkan kecaman terhadap teman sekelompoknya, akan tetapi FINF malah dengan jelas dan keras mengatakan kekurangan teman sekelompoknya. Tuturan tersebut cenderung menjelekkan teman yang seharusnya diajak bekerjasama, maka tuturan tersebut menjadi tidak santun.

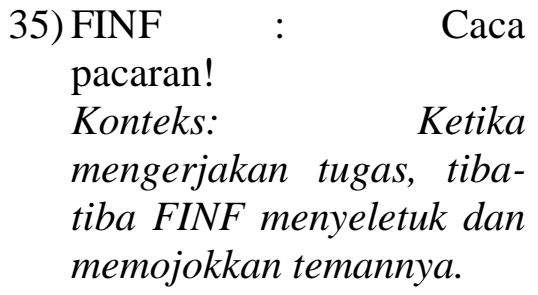

Cara bertutur FINF tidak mencerminkan kesantunan terutama maksim penghargaan. Hal ini terjadi karena FINF mengejek temannya di dalam kelas yang didengar oleh guru dan semua siswa.

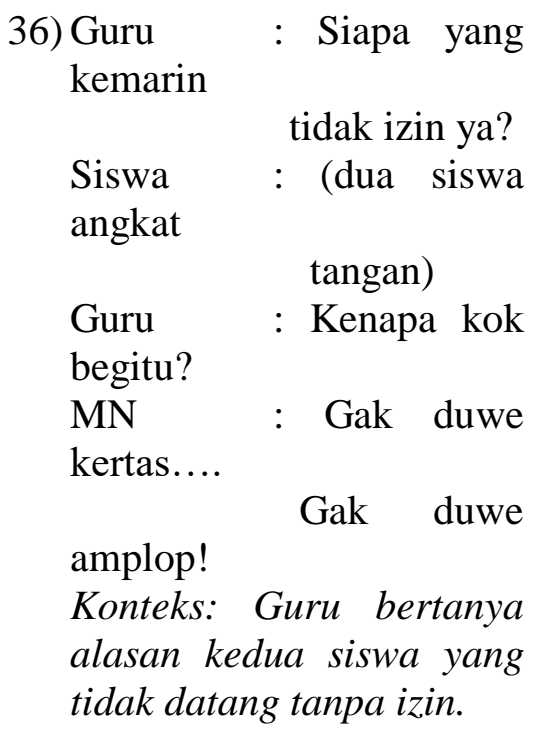

\begin{tabular}{llll} 
& \multicolumn{2}{c}{ tangan) } \\
Guru & : Kenapa kok \\
begitu? & & \\
MN & : & Gak & duwe \\
kertas.... & & \\
amplop! & & Gak duwe
\end{tabular}

MN telah melanggar maksim penghargaan dengan tuturan yang merendahkan dan memojokkan kedua temannya di depan guru dan teman sekelasnya dengan nada sinis.

\section{d. Pelanggaran Maksim Kesederhanaan \\ 37) JFH : Siapa yang maju? \\ Aku maju Konteks: Pada saat diskusi berlangsung, guru menunjuk siswa yang akan maju. Setelah itu, siswa JFH menunjuk diri sendiri untuk maju}


Tuturan tersebut melanggar maksim kesederhanaan karena siswa JFH memberikan kesan sombong terhadap dirinya sendiri dengan menunjuk dirinya sendiri untuk maju dan tidak memberikan kesempatan kepada teman yang lain untuk maju.

38) ADS : Iki lho!
(sambil
melemparkan buku
Konteks: $\quad$ ketemannya)
$\begin{aligned} & \text { memberikan } \quad \text { jawaban } \\ & \text { kepada temannya. }\end{aligned}$

Tuturan tersebut melanggar maksim kesederhanaan karena dituturkan dengan keras. ADS terlihat sombong saat ia memberikan jawabannya dengan cara melempar buku ke temannya.

39) ALNA : Uwis tak jawab

Konteks: memberi tahu temannya bahwa tugas yang ada di buku sudah dikerjakan

Tuturan tersebut telah melanggar maksim kesederhanaan karena tuturan tersebut siswa ALBA menyombongkan diri bahwa tugas yang ada dalam buku tersebut telah selesai dikerjakan (sudah dijawab).

40) CGRM : Udah
Konteks:
pertanyaan
Tuturan CGRM merupakan
tuturan yang melanggar prinsip
kesantunan berbahasa maksim
kesederhanaan karena pada tuturan
tersebut CGRM menyombongkan
diri saat ditanya apa pekerjaannya
sudah selesai dan pilihan kata yang

dipilih sangat singkat yaitu cukup dengan kata "udah".

$\begin{array}{ll}\text { 41) MA } & \text { : Iki lho } \\ \text { Konteks: } & \text { Menunjukkan } \\ \text { sesuatu kepada } & \text { mitra tutur }\end{array}$

Terjadi pelanggaran kesantunan berbahasa pada tuturan tersebut yaitu pelanggaran maksim kesederhanaan.Hal tersebut karena MA tidak mau merendahkan diri dan justru bersikap sombong dengan menunjukkan pekerjaannya kepada mitra tutur.

42) JFH : Udah

Konteks: menjawab pertanyaan yang diberikan berkaitan dengan tugas yang diberikan

Tuturan yang diungkapkan oleh JFH merupakan tuturan yang melanggar prinsip kesantunan berbahasa yaitu maksim kesederhanaan.Hal tersebut karena pada tuturan tersebut JFH tidak berusaha merendahkan diri dan mengurangi pujian terhadap diri sendiri. Diksi 'udah' merupakan bentuk diksi yang menyatakan kesombongan diri penutur.

$\begin{array}{ll}\text { 43) JFH } & \text { : Tiga } \\ \text { Konteks: } & \text { Saat akan } \\ \text { melanjutkan } & \text { pembahasan, } \\ \text { JFH hanya } & \text { menyebutkan } \\ \text { kata"tiga". } & \end{array}$

Tuturan ini merupakan
tuturan yang melanggar prinsip
kesantunan berbahasa
kesederhanaan. Hal tersebut
dikarenakan pada tuturan ini penutur
(JFH) tidak menggunakan diksi
lainnya dan hanya menyebutkan kata
"tiga", sehingga pada tuturan ini

KESANTUNAN BERBAHASA DALAM PROSES PEMBELAJARAN / 153

DI SEKOLAH DASAR

Diani Febriasari' ${ }^{1}$, Wenny Wijayanti ${ }^{2}$ 
penutur tampak merendahkan pihak lain (mitra tutur).

\section{e. Pelanggaran \\ Permufakatan}

Maksim

44) FINF : Yo to.... Tinggali....

Urung nyatet pisan.

Konteks: Guru menyuruh siswa mengumpulkan tugas.

Dalam data tersebut terlihat kalau FINF menggerutu karena terjadi ketidakcocokan antar guru dan dirinya. Seharusnya ketidakcocokan tersebut disampaikan dengan baik sehingga ia tidak terkesan memberontak.

45) Guru : : Kelompok yang lain bagaimana? Semuanya

sama?

atau belum?

Bagaimana? Afifah piye?

AZ : Belum Bu.

Yang

lain.

Konteks: Guru dan siswa berdiskusi untuk menjawab pertanyaan.

Data tuturan tersebut dipandang sebagai bentuk tuturan yang tidak santun karena meminimalkan kesepakatan antara guru dan siswa. Seharusnya walaupun AZ belum selesai mengerjakan tugasnya, ia tidak menyuruh guru untuk menunjuk siswa yang lain untuk menjawab pertanyaan.
46) $\mathrm{GH} \quad$ : Wi ora dijawab

Konteks: pada saat diskusi GH mengatakan pada temannya bahwa nomor yang ditunjuk tidak perlu dijawab

Tuturan GH telah melanggar maksim permufakatan karena $\mathrm{GH}$ langsung mengatakan bahwa nomor yang ditunjuk tidak perlu dijawab tanpa memberikan alternatif jawaban lain pada temannya.

47) YAC : Ogak yo!

Konteks: pada saat diskusi YAC menyatakan bahwa jawabannya tidak seperti itu.

Berdasarkan tuturan tersebut, ujaran YAC terlihat melanggar maksim permufakatan. Ini terjadi karena YAC tidak berusaha membina kecocokan atau kemufakatan dengan mitra tutur dengan membantah pernyataan mitra tutur.

48) GH : Iki opo tugas to? Opo tugas?

Konteks: menanyakan tugas secara terus menerus kepada mitar tuturnya.

Pada tuturan tersebut telat terjadi pelanggaran maksim permufakatan karena pada tuturan tersebut penutur berusaha menyela pembicaraan tanpa melakukan kesepakatan bahwa latihan yang ada di buku merupakan tugas yang harus dikerjakan.

49) YAC : Ndang to! Konteks: menyuruh mitra tutur untuk cepat 
Dalam tuturan tersebut telah terjadi pelanggaran prinsip kesantunan berbahasa yaitu maksim permufakatan. Hal itu terjadi karena YAC tidak memberikan alternatif pada pihak lain dan justru memaksakan kehendak pada pihak lain untuk segera melakukan apa yang diinginkan oleh penutur (YAC).

50) ALNA : Haish...

Konteks: Pada saat kondisi tidak sesuai yang diharapkan oleh ALNA

Pada tuturan itu terjadi pelanggaran maksim permufakatan. Ini terlihat saat ALNA berada pada situasi diskusi dan pada saat mendengarkan pendapat lainnya, si penutur justru mengucapkan kata "Haish" sehingga dikatakan bahwa penutur telah melanggar prinsip kesantunan berbahasa karena tidak berupaya menyepakati situasi tutur.

\section{1) GDK : Sek..sek urung \\ Konteks: Pada saat latihan/tugas dituntut untuk sudah selesai dilakukan}

Tuturan tersebut merupakan tuturan yang melanggar prinsip kesantunan berbahasa maksim permufakatan. Dikatakan melanggar kesantunan berbahasa karena pada tuturan tersebut, penutur (GDK) berusaha untuk tidak menyepakati yang disampaikan dengan tidak mengiyakan tuturan mitra tuturnya dan justru melakukan penawaran dengan "sek..sek urung".

\section{SIMPULAN}

Dari hasil analisis dapat disimpulkan bahwa dalam rekaman video ditemukan tuturan siswa yang mematuhi dan melanggar prinsip kesantunan berbahasa.Pematuhan prinsip kesantunan berbahasa tersebut terdiri dari pematuhan maksim kebijaksanaan, kedermawanan, penghargaan, kesederhanaan, permufakatan, dan kesimpatisan. Pada rekaman video tersebut juga ditemukan tuturan siswa yang melanggar prinsip kesantunan berbahasa yang terdiri dari pelanggaran maksim kebijaksanaan, kedermawanan, penghargaan, kesederhanaan, permufakatan, dan kesimpatisan. Apabila dibandingkan, dalam proses pembelajaran masih banyak siswa yang menggunakan bahasa tidak santun daripada siswa yang menggunakan bahasa santun terhadap guru atau siswa yang lain. Hal ini terjadi karena mereka mengganggap pembelajaran akan terasa lebih santai apabila menggunakan bahasa yang tidak formal.

\section{UCAPAN TERIMA KASIH}

Peneliti mengucapkan terima kasih kepada Direktorat Jendral Penguatan Ristekdikti yang telah membiayai Penelitian Dosen Pemula (PDP) pada pendanaan tahun 2018 ini. Peneliti juga mengucapkan terima kasih kepada 5 Sekolah Dasar di Kota Madiun yang telah membantu menyiapkan data penelitian. 


\section{Daftar Pustaka}

Austin, J.L. 1962. How to Do Thing with Words. Cambridge, Mass. Harvard University Press.

Brown, Penelope and S.C Levinson. 1987. Politeness: Some University in Language. Cambridge University Press.

Chaer, Abdul. 2010. Kesantunan Berbahasa. Jakarta: Rineka Cipta.

Dwijawijaya, dkk. 1974. Sopan Santun Di Dalam Pergaulan. Yogyakarta: Kanisius.

Kusno, Ali. 2014. Kesantunan Bertutur Oleh Orang Tua kepada Anak Di Lingkungan Rumah Tangga. Jurnal Dinamika Ilmu Vol. 14. No 1: 13-25.

Leech, Geofery. 1983. Principles of Pragmatics. London: Longman.

Nuryani.Penerapan Kesantunan Berbahasa dalam Kegiatan Pembelajaran.http://repository.uinjkt.ac.id/dspace/bitstream/123456789/3 1824/3/NURYANI-FITK.pdf. (Diunduh 24 Mei 2017)

Purwo, Bambang Kaswanti. 1990. Pragmatik dan Pengajaran Bahasa. Menyibak Kurikulum 1984. Yogyakarta: Kanisius.

Rahardi, Kunjana. 2005. Pragmatik Kesantunan Imperatif Bahasa Indonesia. Jakarta: Erlangga.

Rustono. 1999. Pokok-Pokok Pragmatik. Semarang: CV. IKIP Semarang Press.

Searle, J. R. 1975." Indirect Speech Acts".Dalam P. Cole dan J. Margon (Penyunting), syntax and semantics. Vol. 3: Speech Acts. New York: Academic Press.

Sumantri, Mulyani. 2014. Perkembangan Peserta Didik. Tangerang Selatan: Universitas Terbuka.

Widiyawanti.Teori Pendidikan. http://widiya.blogs.uny.ac.id/2015/11/02/teoripendidikan/. Diakses tanggal 26 April 2017.

Zamzani, Tadkiroatun Musrifoh, Siti Maslakhah, Ari Listyorini, dan Yayuk Eny R. 2011. "Pengembangan Alat Ukur Kesantunan Bahasa Indonesia dalam Interaksi Sosial Bersemuka".Litera, Volume 10, Nomor 1, April 2011, halaman 35-50. 